NOTES

\title{
A CRITICAL APPRAISAL OF THE JUSTICE DEPARTMENT GUIDELINES FOR GRAND JURY SUBPOENAS ISSUED TO DEFENSE ATTORNEYS
}

The practice of issuing subpoenas to lawyers representing grand jury targets has coine under increasingly heavy fire. ${ }^{1}$ Courts and commentators critical of this practice point to its potential chilling effect on the attorney-chent relationship, ${ }^{2}$ its demoralizing impact on the defense bar, ${ }^{3}$

1. At its February 1986 assembly, the American Bar Association House of Delegates overwhelmingly approved a resolution providing that prosecutors "shall not subpoena nor cause a subpoena to be issued to an attorney to a grand jury without prior judicial approval in circuinstances where the prosecutor seeks to coinpel the attoruey/witness to provide evidence concerning a person who is represented by the attorney/witness." 38 CRIM. L. REP. (BNA) 2386 (Feb. 19, 1986). Delegates voiced deep concern over a perceived mcrease in the governinent's use of grand jury subpoenas directed at attorneys. One delegate spoke of "growing alarm" in the legal profession that the attorney-client relationship and the sixth amendınent right to counsel are "under seige" by prosecutors. Id. at 2387.

Numerous articles critical of this practice have appeared in the past year. See Krieger \& Van Dusen, The Lawyer, the Client, and the New Law, 22 AM. CRIM. L. REv. 737 (1985); Pierce \& Colamarino, Defense Counsel as a Witness for the Prosecution: Curbing the Practice of Issuing Grand Jury Subpoenas to Counsel for Targets of Investigations, 36 HAstings L.J. 821 (1985); Weiner, Federal Grand Jury Subpoenas to Attorneys: A Proposal for Reform, 23 AM. CRIM. L. REv. 95 (1985); Note, Attorney-Client Privilege and the Right to Counsel for the Party Under Investigation, 19 WAKE FOREST L. REV. 487 (1985); Note, Benefactor Defense Before the Grand Jury: The Legal Advice and Incrimination Theories of the Attorney-Client Privilege, 6 CARDozo L. REV. 537 (1985); Kurtz, Attorneys Protest Scrutiny of Fees' Sources, Washington Post, Aug. 14, 1985, at A5, col. 1; Lawyers and the Mob, N.Y. Times, March 30, 1985, at 22, col. 1 (editorial); Ross, Issuance of Subpoenas Upon Lawyers in Criminal Cases: A Defense Attorney's Perspective (March 1985) (article released in connection with public hearings held on this topic by the Association of the Bar of the City of New York on March 20-21, 1985).

Such criticism, however, is not a new phenomenon. See Reform of the Grand Jury System: Hearings on S. 3274 Before the Subcomm. on Constitutional Rights, Senate Comm. on the Judiciary, 94th Cong., 2d Sess. 8486 (1976) (testimony of Melvin B. Lewis); Zwerling, Federal Grand Juries v. Attorney Independence and the Attorney-Client Privilege, 27 HASTINGs L.J. 1263 (1976).

2. See In re Special Grand Jury No. 81-1 (Harvey), 676 F.2d 1005, 1009 (4th Cir.) (noting that issuance of attorney-directed subpoena creates "strong possibility that a wedge will be driven betweeu the attorney and the chent and the relationship will be destroyed"), vacated on other grounds, 697 F.2d 112 (4th Cir. 1982) (en banc).

3. See In re Grand Jury Matters, 593 F. Supp. 103, 107 (D.N. H. 1984) ("[T]o be considered is the ... reluctance of capable attorneys to continue or to consider a full or partial career in the 
and its distortimg effect on the adversarial system. ${ }^{4}$ The Department of Justice, finding itself at the center of this controversy, has recently issued a set of internal guidelines designed to address the problem and stifle the rising tide of criticism. ${ }^{5}$ Federal prosecutors are now required to obtain the authorization of an Assistant Attorney General prior to the issuance

practice of criminal law and the future depletion in the paucity of capable trial lawyers because of a concatenation of events leading to an abuse of process."), aff'd, 751 F.2d 13 (1st Cir. 1984); In re Terkeltoub, 256 F. Supp 683, 685 (S.D.N.Y. 1966) (noting chilling inpact of attorney-directed subpoenas on counsel for defendants in criminal cases).

4. See Pierce \& Colamarino, supra note 1, at 836 (noting deleterious effects on adversary systein that result when grand jury requires attorney to produce evidence relating to client).

5. Section 9-2.161(a) was added to the United States Attorneys' Manual [hereinafter cited as USAM] on July 18,1985 . This section provides:

Because of the potential effects upon an attorney-client relationship that inay result from the issuance of a subpoena to an attorney for information relating to the representation of a client, it is important that the Departinent exercise close control over the issuance of such subpoenas. Therefore, the following guidelines shall be adhered to by all inembers of the Department in any matter involving a grand jury or trial subpoena.

A. In determining whether to issue a subpoena in any inatter to an attorney for information relating to the representation of a chent, the approach nust be to strike the proper balance between the public's interest in the fair administration of justice and effective law enforceinent and individual's right to the effective assistance of counsel.

B. All reasonable attempts shall be made to obtain information froin alternative sources before issuing a subpoena to an attorney for information relating to the representation of a chent, unless such efforts would coinpromise a criminal investigation or prosecution or would impair the ability to obtain such information from an attorney if such attempts prove unsuccessful.

C. All reasonable attempts shall be inade to voluntarily obtain information from an attorney before issuing a subpoena to an attorney for information relating to the representation of a client, unless such efforts would compromise a criminal investigation or prosecution or would impair the ability to subpoena such information from the attorney if such attempts prove unsuccessful.

D. No subpoena may be issued in any matter to an attorney for information relating to the representation of a client without the express autliorization of the Assistant Attorney General of the Criminal Division.

F. [sic] In approving the issuance of a subpoena in any matter to an attorney for information relating to the representation of a client, the Assistant Attorney General of the Criminal Division shall apply the following principles:

(1) In a criminal investigation or prosecution, there must be reasonable grounds to believe that a crime has been or is being committed and that the information sought is reasonably needed for the successful completion of the investigation or prosecution. The subpoena must not be used to obtain peripheral or speculative information;

(2) In a civil case, there must be reasonable grounds to believe that the information sought is reasonably necessary to the successful completion of the litigation;

(3) All reasonable atteinpts to obtain the information from alternative sources shall have proved to be unsuccessful;

(4) The reasonable need for the information inust outweigh the potential adverse effects upon the attorney-client relationship. In particular, the need for the information must outweigh the risk that the attomey will be disqualified from representation of the client as a result of having to testify against the client;

(5) Subpoenas shall be narrowly drawn and directed at material information regarding a limited subject matter and shall cover a reasonably himited period of time; and

(6) The information sought shall not be protected by a valid clain of privilege.

These guidehines on the issuance of grand jury or trial subpoenas to attorneys for information relating to the representation of clients are set forth solely for the purpose of internal Department of Justice guidance. They are not intended to, do not, and may not be relied upon to create any rights, substantive or procedural, enforceable at law by any party in any matter, civil or criminal, nor do they place any limitations on otherwise lawful investigative or litigative prerogatives of the Department of Justice. 
of any subpoena that seeks information relating to the legal representation of a client. ${ }^{6}$ According to the guidelines, internal autlorization to issue a subpoena requires consideration of specific factors, including reasonable need for the information and exhaustion of alternative sources. These factors are to be weighed according to the guidelines' overall directive to balance the public interest in protecting the attorney-client relationship against the need to assure the completion of a successful investigation. ${ }^{7}$

The Department of Justice action was probably spurred by a desire to discourage judicial experimentation with the more drastic reform proposals now gaining currency in various legal and academic circles. The proposal currently receiving the most attention involves a judicial pohicing of attorney-directed subpoenas by the courts of appeals under the aegis of "supervisory power." 8 A second approach contemplates an expansion of the attorney-chent privilege under Rule 501 of the Federal Rules of Evidence.9 Still another approach calls for imcreased protection of the attorney-client relationship in grand jury proceedings through recoguition of a constitutionally-based right to counsel at the grand jury stage. ${ }^{10}$ Underlying each of these alternative proposals is the notion that some form of extra-executive constraint should be placed upon prosecutors when they seek to subpoena counsel representing grand jury targets. In light of this premise, it seens likely that critics will be quick to disparage the new Departinent of Justice guidelines. ${ }^{11}$

This note approaches the problem from a different perspective and suggests that each of the alternative proposals mentioned above involves an unwarranted extension of the protection accorded the attorney-chent relationship at the grand jury stage. Proceeding from the argument that a marked extension of the protection currently afforded is undesirablein that such an extension would unduly restrict the grand jury's ability to carry out its mandate to investigate crime and bring properly founded charges against appropriate individuals ${ }^{12}$-this note suggests that the Department of Justice guidelines represent the most appropriate solution yet proposed. In contrast to the alternative proposals, the new guidelines

6. Id. $\S 9-2.161(\mathrm{a})(\mathrm{D})$.

7. Id. $\S 9-2.161(\mathrm{a})(\mathrm{A})$.

8. See infra notes 31-64 and accompanying text.

9. See infra notes 65-87 and accompanying text.

10. See infra notes 88-108 and accompanying text.

11. Similar criticism was voiced in the early 1970's when the Department of Justice promulgated a set of guidelines to govern the issuance of subpoenas to news reporters. See, e.g., Comment, Constitutional Protection for the Newsman's Work Product, 6 HARv. C.R.-C.L. L. REv. 119, 123 (1970).

12. See infra notes 14-24 and accompanying text. 
appear to present an appropriate response from a separation of powers perspective ${ }^{13}$ and to provide a workable framework within which the adverse effects associated with attorney-directed subpoenas can be minimized. In some isolated respects, however, the guidelines are illconceived and should be revised. This note accordingly suggests a number of modifications to the guidelines as promulgated.

\section{The Attorney-Client Relationship and the GRAND JURY FUNCTION: AN INHERENT TENSION}

Effective law enforcement is a fundamental governmental function in which "the grand jury plays an important, constitutionally mandated role." 14 The Supreme Court has declared that "[t]he grand jury's investigative power must be broad if its public responsibility is adequately to be discharged."15 Central to the effective discharge of its responsibility is the grand jury's right, subject to valid claims of privilege, to "every man's evidence."16

Attorneys have traditionally not been accorded a special exeinption froin the reach of grand jury subpoenas. ${ }^{17}$ The recent crescendo of attorney-directed subpoenas has been due largely to the relevance of certain aspects of attorneys' fees arrangements to racketeering-related investiga-

13. See infra notes $43-53$ and accompanying text.

14. Branzburg v. Hayes, 408 U.S. 665,690 (1972).

15. United States v. Calandra, 414 U.S. 338,344 (1974).

16. Branzburg v. Hayes, 408 U.S. 665,688 (1972) (quoting 8 J. WIGMORE, EvidENCE IN TRIALS AT COMmon LAW $\S 2192$ (McNaughton rev. ed. 1961)); see United States v. Dionisio, 410 U.S. 1, 9-10 (1973) (same).

The importance of society's interest in maintaiming grand jury access to "every man's evidence" is demonstrated in Branzburg v. Hayes, 408 U.S. 665 (1972). In Branzburg, the Court rejected the claim that a reporter could refuse to comply with a grand jury subpoena on first amendment grounds. Maintenance of the grand jury's access to every man's evidence was deemed to override "the cousequential, but uncertain, burden on news gathering that is said to result from insisting that reporters, bike other citizens, respond to relevant questions put to them in the course of a valid grand jury investigation." Id. at 690-91.

17. See In re Grand Jury Matters, 751 F.2d 13, 19 (1st Cir. 1984) (noting absence of "absolute rule that frees an attorney, merely because he is such, to refuse to give unprivileged evidence to a grand jury"); In re Walsh, 623 F.2d 489, 493 (7th Cir.) (attorneys have no privilege to refuse to appear before grand jury), cert. denied, 449 U.S. 994 (1980); In re Special, Sept. 1983, Grand Jury (Klein), 608 F. Supp. 538, 542 (S.D. Ind. 1985) (same); In re Kinoy, 326 F. Supp. 400, 402 (S.D.N.Y. 1970) (lawyers are obliged, "not less than others, to give their non-privileged knowledge to the grand jury"); see also In re Grand Jury Proceedings (Weiner), 754 F.2d 154, 156 (6th Cir. 1985) (attorney's formal right to assert privilege, combined with informal incentives, such as loyalty to client, adequately protect against improper disclosure before grand jury); United States v. Wolfson, $558 \mathrm{~F} .2 \mathrm{~d}$ 59, 66 (2d Cir. 1977) ("[The ordinary presumption is] that a lawyer is competent to protect his client's confidential interests before the grand jury."); United States v. Mackey, 405 F. Supp. 854, 865 (E.D.N.Y. 1975) (attorneys' training concerning privileged and confidential communications make inadvertent breaches unlikely). 
tions. ${ }^{18}$ A material element in a Continuing Criminal Enterprise ${ }^{19}$ prosecution is the financial gain of the enterprise, ${ }^{20}$ and testimony pertaining to the amount of compensation paid an attorney may be useful in demonstrating the existence of substantial unexplained wealth on the part of the client. ${ }^{21}$ In RICO prosecutions, proof of enterprise financial gain, though not a material element of the offense, may nonetheless be viewed by the trier-of-fact as persuasive evidence of a pattern of racketeering activity. ${ }^{22}$ Additionally, evidence that a single benefactor paid the fees of several individuals represented by the same attorney may be useful in establishing the existence of a conspiracy. ${ }^{23}$ Finally, information relating

18. There has also been heightened attention given to the role that a small minority of defense attorneys play in organized crime. See STAFF OF PRESIDENT'S COMMISSION ON ORGANIZED Crime, Materials on Ethical Issues for LAWyers INVolved With ORGaNized Crime CASES (1985); Lawyers Called Organized Crime 'Life Support,' N.Y.L.J., Mar. 11, 1985, at 1, col. 2.

19. 21 U.S.C. $\$ 848$ (1982).

20. Id. $\S 848(\mathrm{~b})(2)(\mathrm{B})$.

21. See, e.g., In re Witnesses Before Special March 1980 Grand Jury, 729 F.2d 489, 490 (7th Cir. 1984) (government claimed that fee information was relevant for investigation of continuing criminal enterprises); United States v. Jeffers, 532 F.2d 1101, 1114 (7th Cir. 1976) (noting that attorney's compelled testimony relating to fees paid by defendant was clearly relevant to issue of substantial income), aff'd in part and vacated in part, 432 U.S. 137 (1977); In re Grand Jury Subpoena Dated Jan. 2, 1985 (Simels), 605 F. Supp. 839, 846 (S.D.N.Y.) (fee information would supply government with additional evidence of "substantial income," an element of 21 U.S.C. § 848), rev'd on other grounds, 767 F.2d 26 (2d Cir. 1985); see also United States v. Barnes, 604 F.2d 121, 147 (2d Cir. 1979) (evidence of possession and receipt of huge sums of money offered to establish that defendant obtained substantial income or resources from criminal enterprise), cert. denied, 446 U.S. 907 (1980).

22. See, e.g., In re Shargel, 742 F.2d 61, 63 (2d Cir.1984) (government sought fee information as evidence of unexplained wealth derived from criminal activity); United States v. Castellano, 610 F. Supp. 1151, 1159 (S.D.N.Y. 1985) (lawyer's activities regarding receipt of payment could indicate existence of enterprise in which attorney's fees were treated as "a cost of doing business, and as a means for selecting attorneys who would function with the crew's interests in mind"); $c f$. United States v. Barnes, 604 F.2d 121, 146 (2d Cir. 1979) ("Evidence of the possession and receipt of huge amounts of money is highly relevant in an operation in which the costs of the commodity and the profits thereon are astronomical."), cert. denied, 446 U.S. 907 (1980); United States v. Magnano, 543 F.2d 431, 437 (2d Cir. 1976) (evidence of defendant's possession of huge sums of cash admissible to show "means" for narcotics trafficking), cert. denied, 429 U.S. 1091 (1977); United States v. Hinton, 543 F.2d 1002, 1012-13 (2d Cir.) (proper in narcotics prosecution to introduce evidence of large expenditures of cash), cert. denied, 429 U.S. 980 (1976).

23. See, eg., In re Grand Jury Subpoena Served Upon Doe, 781 F.2d 238, 251 (2d Cir.) (en banc) (payments made to attorney for representation of third parties highly probative of role of benefactor as head of "enterprise" as defined in RICO, 18 U.S.C. $\$ 1961$ (4) (1982)), cert. denied, 106 S.Ct. 1515 (1986); In re Grand Jury Matters, 751 F.2d 13, 15 (1st Cir. 1984) (government sought fee information to tie each client to drug conspiracy by showing prior arrangements for legal representation of ringleader's "recruits"); In re Shargel, 742 F.2d 61, 64 (2d Cir. 1984) ("[P]ayment of another person's legal fees may imply facts about a prior or present relationship with that person."); In re Grand Jury Proceedings (Pavlick), 680 F.2d 1026, 1028 (5th Cir. 1982) ("[T]he act of furnishing bail and counsel was an act done in furtherance of the illegal scheme itself . . . ."); cf. United States v. Barnes, 604 F.2d 121, 147 (2d Cir. 1979) (defendants had all filed tax returns reflecting large amounts of unexplained income; fact that all these returns had been prepared by the same law firm in Detroit, "a city quite distant from the alleged sites of defendants' operations," found "relevant ... 
to fee amounts could be useful in net worth tax evasion prosecutions. ${ }^{24}$ Where the attorney is the sole source of information pertaining to the amount or circumstances of fee payments, a rule severely restricting grand jury access to that attorney's testimony may in turn severely cripple any attempted investigation.

Despite such concerns, the interests of the public in law enforcement must be balanced witlı other interests of society deemed significant and wortlyy of protection. In this respect, commentators argue that the interests that underlie the protection traditionally accorded the attorney-client relationship are significantly eroded when the attorney is compelled to appear before the grand jury. ${ }^{25}$ Objections to this practice have taken many forms. Critics contend that merely requiring an attorney to appear before a grand jury undermines the trust and confidence of the client who is himself under investigation. ${ }^{26}$ The possibility that an attorney may be subpoenaed is said to chill the attorney-client relationship by discouragmg the client from fully disclosing information necessary for the preparation of a viable defense. ${ }^{27}$

Moreover, critics have repeatedly cliarged that a prosecutor armed with a grand jury subpoena in effect controls the right to counsel. ${ }^{28} \mathrm{Be}$ -

to establish the existence of the conspiracy and its membership"), cert. denied, 446 U.S. 907 (1980); United States v. Pape, 144 F.2d 778, 782 (2d Cir.) (Mann Act prosecution; defendant's having paid legal fees for woman accused of prostitution could be used to show that defendant's "interest in the woman went to the point of retaining and paying for a lawyer to secure her release"), cert. denied, 323 U.S. 752 (1944); United States v. Castellano, 610 F. Supp. 1151, 1160 (S.D.N.Y. 1985) (decision of a number of defendants to retain same lawyer may suggest association among them).

24. See, e.g., In re Klein, 776 F.2d 628, 629 (7th Cir. 1985) (investigation of potential incomc tax violations; subpoena called for retainer contracts and other business and financial documents relating to clients); In re Special Grand Jury No. 81-1 (Harvey), 676 F.2d 1005, 1009 (4th Cir.) (government sought fee information pursuant to investigation of possible tax evasion), vacated on other grounds, 697 F.2d 112 (4th Cir. 1982) (en banc); United States v. Sherman, 627 F.2d 189, 19192 (9th Cir. 1980) (fee amount sought for use in "net worth" approach to computing tax liability); $c f$. In re Grand Jury Witness (Salas), 695 F.2d 359, 360 (9th Cir. 1982) (fee information sought in investigation of individuals associated with tax protest organization).

25. See Pierce \& Colamarino, supra note 1, at 822.

26. See In re Grand Jury Investigation (Sturgis), 412 F. Supp. 943, 946 (E.D. Pa. 1976) ("The very presence of the attorney im the grand jury room, even if only to assert valid privileges, can raise doubts in the client's mind as to his lawyer's unfettered devotion ... and thus impair or at least impinge upon the attorney-client relationship.").

27. See In re Special Grand Jury No. 81-1 (Harvey), 676 F.2d 1005, 1009 n.4 (4th Cir.) ("If the attorney complies with the subpoena and appears before the grand jury behind closed doors, a substantial chilling effect on truthful communications from the client to the attorney thereafter would bc likely, especially if the client is indicted."), vacated on other grounds, 697 F.2d 112 (4th Cir. 1982) (en banc).

28. See In re Grand Jury Subpoena Served Upon Doe, 759 F.2d 968, 975 (2d Cir. 1985) ("[T]he unbridled use of the subpoena would potentially allow the Government, in this and future cases, to decide unilaterally that an attomey will not represent his client."), vacated, 781 F.2d 238 (2d Cir.) (en banc), cert. denied, 106 S. Ct. 1515 (1986); In re Grand Jury Investigation (Sturgis), 412 F. Supp. 943, 945-46 (E.D. Pa. 1976) (calling target's attorney before the grand jury may lead to disqualifica- 
cause a lawyer's grand jury testimony may be adverse to the client, and because the government may on the basis of that testimony decide to call the attorney as a witness at a subsequent trial, critics see the grand jury subpoena as a vehicle by which the government can selectively bring about the disqualification of defense counsel. Such a result not only would deny a client his choice of counsel, ${ }^{29}$ but, were it to be routinely repeated, would be likely to create a substantial disincentive to the practice of criminal hitigation. Finally, pervading these concerns is the possibility that an untenable conflict of interest might develop should the subpoenaed attorney himself become a target of the grand jury investigation. ${ }^{30}$

\section{Shortcomings OF Alternative Remedial Solutions}

Each approach examined in this section-use of the courts' supervisory power to police of attorney-directed subpoenas, expansion of the attorney-client privilege, and constitutional protection of the attorneychent relationship at the grand jury stage--is premised upon the wellfounded belief that the attorney-client relationship may be eroded when the attorney is made to appear before the grand jury. Yet the choice of which corrective measures are most appropriate must be analyzed in light of competing societal interests and separation of powers concerns. This note applies such an analysis to each of the alternative approaches

tion; attorney-client relationship may be impaired); Krieger \& Van Dusen, supra note 1, at 739 (use of grand jury subpoena power combined with threat that prosecutors may seek forfeiture of attorneys' fees under the Comprehensive Forfeiture Act of 1984 results in a situation where the "government controls the right to counsel").

29. The right of a defendant to be represented by chosen counsel has been held to be a qualified sixth amendment right. See, e.g., United States v. Cunningham, 672 F.2d 1064, 1070 (2d Cir. 1982) (although not an absolute right, defendant's right to counsel of his own choosing is of constitutional dimensions), cert. denied, 104 S. Ct. 2154 (1984); United States v. Bubar, 567 F.2d 192, 203 n.18 (2d Cir.) (defendant has a right to counsel of his own choice), cert. denied, 434 U.S. 872 (1977). The precise nature of a grand jury witness's right to chosen counsel is, however, unclear. The weight of current authority holds that a grand jury witness has no rights at all under the sixth amendment. See infra note 96 and accompanying text. Nonetheless, it is noteworthy that even in the context of disqualification motions in civil litigation, courts have consistently averted to both the policy against arbitrary infringement of choice of counsel, see, e.g., Woods v. Covington County Bank, 537 F.2d 804,810 (5th Cir. 1976), and the pohicy against the use of disqualification motions as a tactical device to deprive an opponent of competent counsel, see, e.g., Greenebaum Mountain Mortgage Co. v. Pioneer Nat'l Title Ins. Co., 421 F. Supp. 1348, 1352 (D. Colo. 1976). One commentator has suggested that there is no reason why a grand jury witness's choice of counsel should not be accorded at least the same level of solicitude. See Moore, Disqualification of an Attorney Representing Multiple Witnesses Before a Grand Jury: Legal Ethics and the Stonewall Defense, 27 UCLA L. REV, 1, 18-20 (1979).

30. See, e.g., United States v. Wolfson, 558 F.2d 59, 65 (2d Cir. 1977) (discussing appellant's claim that, because his lead counsel at trial was a subject of alleged government investigation, he was deprived of effective assistance of counsel). 
and concludes that each exhibits substantial shortcomings. The guidelines issued by the Department of Justice, because their implementation provides adequate safeguards without unduly burdening the grand jury's constitutional function and without contravening the principle of separation of powers, emerge as the best response.

\section{A. Supervisory Power.}

One approach that has won support in academic and legal circles ${ }^{31}$ is the "supervisory power"32 solution pioneered by the United States Court of Appeals for the Fourth Circuit in In re Special Grand Jury No. 81-1 (Harvey). ${ }^{33}$ Before an attorney-directed subpoena will be judicially enforced, the Harvey rule requires that the government make a preliminary showing "that the information sought is relevant to and needed for an investigation being conducted by the grand jury." ${ }^{34}$ The Harvey rule is a variant of the rule pertaining to subpoenas duces tecums established by the United States Court of Appeals for the Third Circuit in United States v. Schofield. ${ }^{35}$ In Schofield, the court held that before a witness could be held in contempt for failure to coinply with a subpoena duces tecum, the government must make a "preliminary showing by affidavit that each item is at least relevant to an investigation being conducted by the grand jury and properly within its jurisdiction, and is not sought primarily for another purpose." 36 In adapting the Schofield rule to subpoenas issued to attorneys, the Harvey court determined that the preliminary

31. See Pierce \& Colamarino, supra note 1, at 867-71; Ross, supra note 1, at 38-40.

32. The term "supervisory power" has come to describe the authority underlying a broad range of judicial action. Generally, courts use this term to refer to an inherent judicial power to oversee and preserve the integrity of judicial proceedings. For discussions of the origins and development of the supervisory power doctrine, see Beale, Reconsidering Supervisory Power in Criminal Cases: Constitutional and Statutory Limits on the Authority of the Federal Courts, 84 Colum. L. REv. 1433 (1984); Note, The Supervisory Power of the Federal Courts, 76 HARv. L. Rev. 1656 (1963).

33. 676 F.2d 1005 (4th Cir.), vacated on other grounds, 697 F.2d 112 (4th Cir. 1982) (en banc).

Harvey no longer has precedential value in the Fourth Circuit. The panel opinion was withdrawn after the target whose attorney was subpoenaed had been indicted and became a fugitive from justice. The subsequent history of the Harvey case is discussed in In re Grand Jury Proceedings in the Matter of Freeman, 708 F.2d 1571, 1575 (11th Cir. 1983).

The United States Court of Appeals for the Second Circuit adopted the Harvey supervisory power approach but limited the Harvey rule by holding that the preliminary showing would be required only when the testimony would result in the attorney's disqualification. In re Grand Jury Subpoena Served Upon Doe, 759 F.2d 968, 975 (2d Cir. 1985). Doe was subsequently vacated en banc. In re Grand Jury Subpoena Served Upon Doe, 781 F.2d 238 (2d Cir.) (en banc), cert. denled, 106 S.Ct. 1515 (1986).

34. Harvey, 676 F.2d at 1011.

35. In re Grand Jury Proceedings (Schofield), 486 F.2d 85 (3d Cir. 1973), later appeal, 507 F.2d 963 (3d Cir.), cert. denied, 421 U.S. 1015 (1975).

36. Id. at 93 . 
affidavit must show the additional element of "need." 37

Other circuits considering the issue have declined to adopt the Schofield preliminary showing requirement for subpoenas duces tecums. ${ }^{38} \mathrm{~A}$ number of courts have also expressly rejected the attorney subpoena version of that rule. ${ }^{39}$ Those courts refusing to adopt the supervisory power approach have commonly done so on the ground that its application would unduly disrupt and hamper grand jury proceedings. ${ }^{40}$ Reluctance to impose a Schofield-like requirement also flows from deference to the

37. The court stated that the prosecution must make two inquiries when making the showing of need: (1) whether "the information sought [is] necessary or important to the grand jury investigation," and (2) whether "the subpoenaed attorney [is] the best source for the information." Harvey, 676 F.2d at 1011 n.6. The court continued that a "showing that the information cannot be obtained from another source would, of course, be important to, but not necessarily conclusive for, the second inquiry." $I d$.

38. See In re Grand Jury Subpoena Served Upon Doe, 781 F.2d 238, 243 (2d Cir.) (en banc), cert. denied, 106 S.Ct. 1515 (1986); In re Grand Jury Subpoena (Battle), 748 F.2d 327, 330 (6th Cir. 1984); United States v. Santucci, 674 F.2d 624, 629 (7th Cir. 1982), cert. denied, 459 U.S. 1109 (1983); In re Pantojas, 628 F.2d 701, 704-05 (1st Cir. 1980); Umited States v. Wilson, 614 F.2d 1224, 1227-28 (9th Cir. 1980); In re Liberatore, 574 F.2d 78, 83 (2d Cir. 1978); In re Grand Jury Proceedings (Guerrero), 567 F.2d 281, 283 (5th Cir. 1978); In re Grand Jury Investigation (McLean), 565 F.2d 318, 320 (5th Cir. 1977); In re Grand Jury Proceedings (Hergenroeder), 555 F.2d 686, 686 (9th Cir. 1977) (per curiam); In re Berry, 521 F.2d 179, 184 (10th Cir.), cert. denied, 423 U.S. 928 (1975); In re Grand Jury Proceedings (Universal Mfg. Co.), 508 F.2d 684, 686 n.2 (8th Cir. 1975) (per curiain).

39. See In re Klein, 776 F.2d 628, 632-34 (7th Cir. 1985); In re Grand Jury Proceedings (Weiner), 754 F.2d 154, 155-56 (6th Cir. 1985); In re Grand Jury Proceeding (Schofield), 721 F.2d 1221, 1223 (9th Cir. 1983); In re Grand Jury Proceedings in Matter of Freeman, 708 F.2d 1571, 1575 (11th Cir. 1983); In re Grand Jury Proceedings (Bowe), 694 F.2d 1256, 1258 (11th Cir. 1982); In re Slaughter, 694 F.2d 12S8, 1260 (11th Cir. 1982).

40. See, e.g., In re Grand Jury Subpoena Served Upon Doe, 781 F.2d 238, 248 (2d Cir.) (en banc) (imposition of "need" showing "would hamper severely the investigative function of the grand jury, if not stop the grand jury 'dead in its tracks" "), cert. denied, 106 S.Ct. 1515 (1986); In re Klein, 776 F.2d 628, 631 (7th Cir. 1985) (emphasizing the need not to delay grand jury proceedings: "In the meantime targets are free, inemories of other witnesses are fading, evidence is disappearing, the grand jury may have difficulty proceeding against other targets, and events may escape scrutiny as the statute of limitations takes its toll."); In re Grand Jury Proceedings (Weiner), 754 F.2d 154, 156 (6th Cir. 1985) (imposition of preliminary showing requirement would "crcate an additional impediment to the grand jury's search for relevant information"); In re Grand Jury Proceedings (Hergenroeder), 555 F.2d 686, 686 (9th Cir. 1977) (per curiam) ("In view of the presumption that the government obeys the law, we see no reason to injeet into routine grand jury investigations the delay and imposition upon district courts that will be opened up by a rule institutionalizing these disclaiming affidavits.").

The Supreme Court has voieed a similar concern that delay in the grand jury context be minimized. In United States v. Dionisio, 410 U.S. 1 (1973), the Court stated, "Any holding that would saddle a grand jury with minitrials and prehminary showings would assuredly impede its investigation and frustrate the public's interest in the fair and expeditious administration of the criminal laws." Id. at 17. Cf. H.R. ReP. No. 1064, 96th Cong., 2d Sess. 10 (1980) ("DDelay] . . . may be intolerable from a law enforcement standpoint, e.g., in investigating such crimes as highly mobile drug trafficking or ongoing crimes which endanger the health and safety of the public, or where the ability to obtain a conviction through eyewitness identification diminishes rapidly with the passage of time."). 
principle that grand jury subpoenas should not ordinarily be subject to preliminary review by the courts for relevance and need. ${ }^{41}$ Alternatively, the preliminary showing approach has been criticized on the ground that its imposition in fact has only ininimal effect, since the showing of need in the grand jury context can be easily made. ${ }^{42}$

Thus the advisability of the supervisory power approach to attorney subpoenas is questionable because it may impede the grand jury process. Apart from this practical concern is a more fundamental matter arising from separation of powers considerations. ${ }^{43}$ One coinmentator has persuasively questioned the authority of the courts of appeals to establish procedural rules for the district courts where a statutory or constitutional basis is wanting. ${ }^{44}$ Though trial courts possess the poiver to quash subpoenas that are oppressive or unreasonable, ${ }^{45}$ courts of appeals have no parallel statutory authority to impose blanket procedural rules pertaining to grand jury subpoenas. ${ }^{46}$ When a court of appeals without constitutional or statutory authority imposes a rule intended to control the conduct of federal prosecutors, separation of powers concerns are implicated. ${ }^{47}$ As a panel in the Ninth Circuit recently stated: "A federal court that imposes sanctions on executive conduct that is otherwise permitted by the Constitution, a federal statute or a rule will most likely be invading the executive sphere rather than protecting itself from invasion." $" 48$

41. See United States v. Dionisio, 410 U.S. 1, 15-16 (1973) ("The [grand] jurors may act on tips, rumors, evidence offered by the prosecutor, or their own personal knowledge . . . . And a sufficient basis for an indictment may only emerge at the end of the investigation when all the evidence has been received.") (citations omitted); In re Special February 1975 Grand Jury (Lopez), 565 F.2d 407, 411 (7th Cir. 1977) ("A grand jury is not under a duty to disclose reasons for the information it seeks."); In re Berry, 521 F.2d 179, 184 (10th Cir.) ("Relevancy and materiality are not pertinent to subpoena enforcement."), cert. denied, 423 U.S. 928 (1975).

42. Although no reliable empirical evidence exists, the Schofield rule has been characterized as not having "caused any serious disruption of grand jury proceedings." Hearings on H.R. 94 Before the Subcomm. on Immigration, Citizenship, and International Law of the House Comm. on the Judiciary, 95th Cong., 1st Sess. 1589 (1977) (memorandum by Alfred M. Nittle and Martin H. Belsky). One reason for this lack of disruption may lie in the simple fact that a mere recitation of the fact that a valid investigative purpose exists suffices to establish need. See Weiner, supra note 1, at 121 n.161.

43. See Beale, supra note 32 , at 1521.

44. Id.

45. See FED. R. CR1M. P. 17(c).

46. See In re Grand Jury Matters, 751 F.2d 13, 19 (1st Cir. 1984) (emphasizing that decision whether to quash attorney-directed subpoena "is one that turns on particular facts as evaluated by a district court"); In re Pantojas, 628 F.2d 701, 705 (1st Cir. 1980) ("The practical responsibility for controlling grand jury excesses lies with the district court ....").

47. Beale, supra note 32, at 1521; Note, A Separation of Powers Approach to the Supervisory Power of Federal Courts, 34 STAN. L. REv. 427, 448-49 (1982).

48. United States v. Gatto, 763 F.2d 1040, 1046 (9th Cir. 1985); cf. In re Klein, 776 F.2d 628, 632 (7th Cir. 1985) ("A grand jury tracks down leads, and even innocent-looking information may 
The Supreme Court itself has condemned unwarranted judicial interference with the issuance of grand jury subpoenas. In United States $v$. Dionisio, ${ }^{49}$ the Court held that the fourth amendinent requires no preliminary showing of reasonableness before a grand jury witness can be coinpelled to furnish a voice exemplar. ${ }^{50}$ The Court noted that if the grand jury is "to approach the proper perfornance of its Constitutional mission, it must be free to pursue its investigations unhindered by external influence or supervision so long as it does not trench upon the legitimate rights of any witness called before it." 51 The Third Circuit in Schofield distinguished Dionisio, noting that Dionisio held only that the Constitution required no preliminary showing and therefore did not limit the lower courts' supervisory powers over the conduct of grand jury proceedings. ${ }^{52}$ This distinction has found few proponents im the federal judiciary. Most courts mstead derive from Dionisio the broader proposition that the judiciary should give wide berth to the manner in which grand jury proceedings are conducted. ${ }^{53}$

Thus, the supervisory power approach is subject to attack on the ground that it contemplates impermissible judicial interference within a sphere recognized as the proper domain of executive discretion. Critics of attorney subpoenas have advanced a separation of powers argument of their own, however, and have argued that the exercise of the prosecutorial discretion in question constitutes the usurpation of a judicial function. These critics have charged that some federal prosecutors may issue a subpoena upon an attorney with the ulterior notive of ultimately effecting the attorney's disqualification. ${ }^{54}$ This charge is illfounded for two reasons. First, it must be borne in mind that "the Constitution ... [will] not tolerate the transformation of the grand jury into an imstrument of oppression." 55 Under federal criminal procedure, grand jury subpoenas are subject to motions to quash on the ground of oppressiveness, ${ }^{56}$ and a district court would accordingly be obliged to grant a motion to quash on the ground that the subpoena was issued with the

be useful .... How much information is 'enough' is a matter for the judgment of the grand jurors and the prosecutor rather than the courts.").

49. 410 U.S. 1 (1973).

50. Id. at 8 .

51. Id. at $17-18$.

52. In re Grand Jury Proceedings (Schofield), 486 F.2d 85, 89 (3d Cir.), later appeal, 507 F.2d 963 (3d Cir. 1973), cert. denied, 421 U.S. 1015 (1975).

53. See supra note 41 and accompanying text.

54. See supra note 28.

55. United States v. Dionisio, 410 U.S. 1, 12 (1973) (discussing Branzburg v. Hayes, 408 U.S. 665 (1972)).

56. FED. R. CRIM. P. 17(c). Although Rule 17(c) on its face applies only to subpoenas for documents, in In re Grand Jury Matters, 593 F. Supp. 103 (D.N.H.), aff'd, 751 F.2d 13 (1st Cir. 
primary purpose of disrupting an attorney-client relationslip. ${ }^{57}$ For example, the United States Court of Appeals for the First Circuit recently affirmed a district court decision to quash grand jury subpoenas issued upon attorneys representing chents in litigation pending in state court on the ground that the timing of the subpoenas made them unreasonable and oppressive. 58

The preliminary showing requirement would probably be of questionable value as an aid in the review of such motions to quash. Even in the Third Circuit, a Schofield affidavit is sufficient if it merely recites some legitimate investigative purpose. ${ }^{59}$ Consequently, there is little reason to believe that the preliminary slowing requirement will lead to the development of a factual record sufficient to serve as a basis for ruling on a motion to quash.

Secondly, no court has held that a disqualification motion may be sustained solely because an attorney has given testimony before the grand jury that is possibly adverse to his client. There is little case law on the precise point. However, courts have routinely applied sixtli amendment standards to judge disqualification motions brouglit on other grounds in the grand jury context. ${ }^{60}$ The subject of disqualification will be taken up more thoroughly below in the discussion of the Department of Justice guidelines; ${ }^{61}$ the point here is simply that there is hittle case law suggesting that the decision to subpoena an attorney before the grand jury irrevocably spells the disqualification of the attorney or in any substantial way derogates from the judicial determination that must be made in connection with a disqualification motion.

1984), the rule was invoked to quash subpoenas requiring the appearance of attorneys before a grand jury.

57. See In re Klein, 776 F.2d 628, 633 n.3 (7th Cir. 1985) ("Of course, if the district court finds that a subpoena is sought for the purpose of disrupting the relationship between a target and his attorney, then the court could in its discretion quash the subpoena under Fed. R. Crim. P. 17(c) as unreasonable or oppressive.").

In an analogous context, the Supreme Court warned that "[o]fficial harrassment [through the issuance of grand jury subpoenas] of the press undertaken not for the purposes of law enforcement but to disrupt a reporter's relationship with his news sources would have no justification." Branzburg v. Hayes, 408 U.S. 665, 707-08 (1972). Likewise, a district court would presumably be obliged to quash an attorney-directed subpoena issued solely to disrupt an attorney-client relationship. Additionally, attorney-directed subpoenas are subject to being quashed if used in aid of purposes unrelated to the grand jury function. See, eg., In re Grand Jury Subpoena Duces Tecum Dated Jan. 2, 1985 (Simels), 767 F.2d 26, 30 (2d Cir. 1985) (quashing attorney-directed subpoena used for impermissible purpose of preparing for trial); In re Stolar, 397 F. Supp. 520,523 (S.D.N.Y. 1975) (quashing attorney-directed subpoena used as an adjunct to FBI investigation).

58. In re Grand Jury Matters, 751 F.2d 13 (1st Cir. 1984).

59. Weiner, supra note 1, at 121 (discussing implementation of the Schofield rule in the Third Circuit).

60. See infra note 130.

61. See infra notes $126-35$ and accompanying text. 
The Massachusetts Supreme Judicial Court recently adopted an approach similar but not identical to the Harvey rule. ${ }^{62}$ Like the supervisory power approach, the Massachusetts rule contemplates judicial supervision of attorney subpoenas. Unlike the federal supervisory power approach, however, judicial oversight is not brought to bear at the stage of subpoena enforcement. Instead, Massachusetts prosecutors who do not obtain judicial authorization for the issuance of the subpoena are subject to professional discipline. ${ }^{63}$

The Massachusetts rule, insofar as it requires judicial approval based on a preliminary showing by the prosecutor, is subject to the same objections as those raised against the Harvey rule: it may impede the investigatory function of the grand jury and cause unnecessary delay in a context in which time is of the essence. ${ }^{64}$ On the other hand, the remedy conteinplated-professional discipline-would impair the operation of the grand jury less than would the subpoena nonenforcement remedy conteinplated by the Harvey rule. Nevertheless, the across-the-board applicability of the Massachusetts rule does impose an undesirable constraint on prosecutorial discretion, and the imposition of disciplinary sanctions would be better confined to cases of demonstrated bad faith or harassment.

\section{B. Attorney-Client Privilege.}

As an alternative to the supervisory power solution, some authorities have suggested that judicial expansion of the attorney-client privilege would alleviate many of the problems associated with attorney-directed subpoenas. Rule 501 of the Federal Rules of Evidence provides that privileges "shall be governed by the principles of the common law as they may be interpreted by the courts of the United States." 65 In effect, Rule 501 authorizes the federal courts to expand and develop common law

62. The rule, effective January 1, 1986, states:

It is unprofessional conduct for a prosecutor to subpoena an attorney to a grand jury without prior judicial approval in circumstances where the prosecutor seeks to compel the attorney/witness to provide evidence concerning a person who is represented by the attorney/witness.

Mass. Sup. Judicial CT. R. 3:08 (PF15). See also Massachusetts Adopts Rule on Subpoenaing Attorneys, 38 CRIM. L. REP. (BNA) 2140 (Nov. 13, 1985).

63. Id.

64. The application of the Massachusetts rule to federal prosecutors was challenged in federal district court by the United States Attorney for Massachusetts on two grounds: (1) lawyers who believe that the subpoena will threaten the attorney-client privilege may move to quash the subpoena, and (2) the State of Massachusetts, by imposing this requirement on federal prosecutors, violates the supremacy clause since such advance judicial approval is not required under federal law. The court rejected both arguments. See Weld v. Klublock, No. 85-4809, slip op. (D. Mass. Feb. 28, 1986).

65. FED. R. Evid. 501. 
privileges. ${ }^{66}$ Judicial initiative pursuant to this invitation would not be unprecedented. For example, federal courts have recognized a common law privilege for newsreporters under Rule 501 in both criminal and civil cases. ${ }^{67}$

The attorney-chent privilege might be expanded in two possible directions. The first would involve severing the attorney-client privilege from its traditional mooring in confidential communications and according it the greater breadth associated with a "status" privilege. Uंnder this approach, the attorney-chent relationship itself would be viewed as suffciently important to society to justify insulating it completely from inquiry. Such an approach is the logical extension of the argument that the relationship of trust and confidence essential to an effective attorney-client relationship is eroded when the attorney is compelled to testify before the grand jury. ${ }^{68}$ An analogy imight be drawn to the marital testimonial privilege, which finds its modern justification in "its perceived role in fostering the harinony and sanctity of the marriage relationship,"69 a relationship that, like the attorney-client relationship, is deemed to serve important social purposes.

A "status" expansion of the attorney-client privilege, however, would be problematic in several respects. Adoption of a status-based privilege would completely repudiate the accommodation of competing social interests reflected in the traditional privilege based on confidential commumications. ${ }^{70}$ Under a status-based regine, probative infornation would be barred from disclosure no matter how compelling the govern-

66. For a discussion of the policy of Rule 501, see C. WRIGHT \& K. GrAHAM, FEDERAL Practice ANd Procedure, $\$ 5422$ (1980).

67. See United States v. Cuthbertson, 630 F.2d 139, 146 (3d Cir. 1980) (criminal), cert. denied, 449 U.S. 1126 (1981); see also Los Angeles Memorial Coliseum Comm'n v. NFL, 89 F.R.D. 489, 492-95 (C.D. Cal. 1981) (civil).

68. See In re Special Grand Jury No. 81-1 (Harvey), 676 F.2d 1005, 1009 n.4 (4th Cir.) ("If the attorney complies with the subpoena and appears before the grand jury behind closed doors, a substantial chilling effect on truthful communications from the client to the attorney thereafter would be likely, especially if the client is indicted."), vacated on other grounds, 697 F.2d 112 (4th Cir. 1982) (en banc).

69. Trammel v. United States, 445 U.S. 40, 44 (1980).

70. One commentator has stated:

Once the privilege is extended beyond cominunications to bar an inquiry about actions taken by a lawyer for the benefit of the client ...., there is a danger that clients will use tle attorney-client relationship to immunize public activities from public scrutiny and to prevent investigative bodies ... from inquiring into actions for which a client may be legally responsible. The loss of information could be substantial. To avoid this loss of information, courts are justified in restricting the privilege. The privilege is intended to foster cominunications, not to make the attorney an agent whose agency is not subject to judicial inquiry.

Saltzburg, Communication Falling Within the Attorney-Client Privilege, 66 IowA L. REv. 811, 823 24 (1981). 
ment's need. ${ }^{71}$ Such a broad privilege would create an incentive to use attorneys as "conduits of information or of commodities necessary to crimimal schemes."72 Indeed, criminal activity on the part of attorneys themselves would become inore difficult to uncover.

Furthermore, the analogy to the inarital testimonial privilege-the paradigm status privilege--does not withstand close scrutiny. The marital testimonial privilege has been much criticized, ${ }^{73}$ and its continued vitahity today is probably due mostly to a resigned recognition that spousal testimony is inherently unreliable and therefore of questionable value when compelled. In contrast, an attorney is an officer of the court, and expectations concerning trustworthiness are justifiably greater with regard to his testimony. Both the heightened trustworthiness of attorney testinony and the fact that such evidence will in many cases be essential to a successful investigation militate for striking a different balance than that which has been struck in the case of spousal testimony.

The attorney-chent privilege might also be expanded in a second direction. An attorney-client privilege incorporating the client's privilege against self-mcrimination lias been developed by some courts to protect attorney fee information from compelled disclosure. ${ }^{74}$ This selfincrimination gloss has been defined differently by the various courts employing it. The United States Court of Appeals for the Fifth Circuit has held that information subpoenaed from an attorney is protected if disclosure "would yield substantially probative links in an existing chain of inculpatory events or transactions."75 The United States Court of Appeals for the Ninth Circuit lias held that otherwise unprivileged information may be protected froin disclosure if it would "implicate that client in

71. Where the attorney-client privilege is held to apply, courts have not been willing to make ad hoc determinations based on balancing the interests involved in the particular case. See Note, The Attorney-Client Privilege: Fixed Rules, Balancing, and Constitutional Entitlement, 91 HARV. L. REV. 464, $468-69$ (1977).

72. In re Shargel, 742 F.2d 61, 64 (2d Cir. 1984).

73. See $8 \mathrm{~J}$. WIGMORE, supra note $16, \S 2228$ (labeling the inarital testimonial privilege "the merest anachronism in legal theory and an indefensible obstruction to truth in practice").

74. See, e.g., In re Grand Jury Proceedings (Lawson), 600 F.2d 215, 218-19 (9th Cir. 1979) (attorney had "just" reason to assert attorney-client privilege where disclosure of names and fee arrangements would inplicate clients in past conspiracy); In re Grand Jury Proceedings (Jones), 517 F.2d 666, 674 (5th Cir. 1975) ("II]nformation, not normally privileged, should . . be protected when so much of the substance of the communications is already in the governinent's possession that additional disclosures would yield substantially probative links in an existing chain of inculpatory events or transactions."); see also In re Grand Jury Investigation (Tinari), 631 F.2d 17, 19 (3d Cir. 1980) (noting that fee arrangements "might be protected . . . if the person asserting the privilege can show a strong probability that disclosure of the fact of retention or of the details of a fee arrangement would implicate the client in the very criminal activity for which legal advice was sought"), cert. denied, 449 U.S. 1083 (1981).

75. In re Grand Jury Proceedings (Jones), 517 F.2d 666, 674 (5th Cir. 1975). 
the very criminal activity for which legal advice was sought."76

The genesis of the self-incrimination variation of the attorney-client privilege can be traced to the Ninth Circuit's decision in Baird v. Koerner. ${ }^{77}$ In Baird, an attorney submitted a payment to the Internal Revenue Service (IRS) at the request of several anonymous clients. Having been advised by the attorney that they had understated their taxes in preceding years, the chents sought to make the payment through the attorney in order to avert possible prosecution. After he had submitted the payment, the attorney was served with an IRS summons requesting the names of the clients. The Ninth Circuit held that the attorney's refusal to disclose the identities was justified because the content of his legal advice to the anonymous chents had already been revealed, and the further act of revealing the chents' identities would hink specific individuals to that content and thus anount to a disclosure of confidential attorneyclient communications. ${ }^{78}$

Several circuits have expressed disdain for the "incrimination approach" to the attorney-chent privilege. This disdain stems largely from a reluctance to part with the precepts of the traditional privilege. The attorney-client privilege in its traditional form serves to protect only confidential communications. ${ }^{79}$ The underlying justification of the privilege is that the adversarial process can only operate through the preparation and pursuit of vigorous defenses. ${ }^{80}$ Full disclosure by the client is seen as essential to that end, and the privilege is designed to encourage such disclosure. ${ }^{81}$ Because the operation of the privilege denies the governinent access to potentially probative information, however, courts have long required that it be strictly construed. ${ }^{82}$ Courts have accordingly held

76. United States v. Hodge \& Zweig, 548 F.2d 1347, 1353 (9th Cir. 1977).

77. 279 F.2d 623 (9th Cir. 1960).

78. Id. at 630 .

79. In re Grand Jury Proceedings, 727 F.2d 1352, 1356-58 (4th Cir. 1984) (attorney-client privilege applies only where communication sought to be protected is intended to be confidential).

80. Cf. United States v. Nobles, 422 U.S. 225, 238 (1975) ("The interests of society and the accused in obtaining a fair and accurate resolution of the question of guilt or innocence demand that adequate safeguards assure the thorough preparation and presentation of each side of the case.").

81. See Fisher v. United States, 425 U.S. 391, 403 (1976) (purpose of attorney-client privilege is "to encourage clients to make full disclosure to their attorneys").

82. Id. ("[S]ince the privilege has the effect of withholding relevant information from the factfinder, it applies only when necessary to achieve its purpose."); United States v. Nixon, 418 U.S. 683,710 (1974) ("[E]xceptions to the demand for every man's evidence are not lightly created nor expansively construed, for they are in derogation of the search for truth."); In re Grand Jury Proceedings, 727 F.2d 1352, 1355 (4th Cir. 1984) (attorney-client privilege is to be "strictly confined"); In re Grand Jury Investigation No. 83-2-35, 723 F.2d 447, 451 (6th Cir. 1983) (because "invoeation of the privilege before the grand jury inay jeopardize an effective and comprehensive investigation into alleged violations of the law," it must be "narrowly construed"), cert. denied, $104 \mathrm{~S} . \mathrm{Ct} .3524$ (1984); see also $8 \mathrm{~J}$. WIGMORE, supra note $16, \S 2291$ (attomey-client privilege must be strictly 
that fee information lacking a confidential communication predicate is not protected by the attorney-client privilege, even where it nay incriminate the chient. ${ }^{83}$ Thus, the traditional attorney-chent privilege has not been construed to enable an attorney to assert vicariously his client's selfincrimination privilege in the absence of a confidential communication predicate. ${ }^{84}$

Were an "incrimination approach" expansion of the attorney-chent privilege uniformly recognized with respect to fee arrangements, probative information would be strictly barred from disclosure no matter how

construed because it is inconsistent with general duty to disclose and impedes investigation of the truth).

83. See In re Shargel, 742 F.2d 61, 63 (2d Cir. 1984). The Shargel court noted that a general rule requiring disclosure of the fact of consultation and the payment of a fee does not force attorneys to caution against disclosure and thus render ill-formed advice. Such information is therefore not protected by the privilege even though it may mcriminate the client. Id. See also In re Witnesses Before Special March 1980 Grand Jury, 729 F.2d 489, 491-92 (7th Cir. 1983) (rejecting "incrimination rationale" for finding exception to rule that fee information is not privileged); United States v. Davis, 636 F.2d 1028, 1044 (Sth Cir.) (payment of fees is generally not privileged inforination because such payments are not communications made for purpose of obtaining legal advice), cert. denied, 454 U.S. 862 (1981); United States v. Sherman, 627 F.2d 189, 191-92 (9th Cir. 1980) (information regarding fee arrangement ordinarily is not part of subject matter of professional consultation and therefore not privileged communication even though it may evidence wrongdoing by the client); In re Grand Jury Empanelled Feb. 14, 1978 (Markowitz), 603 F.2d 469, 473 n.4 (3d Cir. 1979) (emphasizing that it is link between client and commumication, rather than link between client and possibility of potential criminal prosecution, which brings client identity under the attorneyclient privilege); United States v. Jeffers, 532 F.2d 1101, 1115 (7th Cir. 1976) (altlough fee information was incriminatory, "the crucial question is whether such disclosure violates the substance of a confidential communication between attorney and client'), aff'd in part and vacated in part on other grounds, 432 U.S. 137 (1977); United States v. Hodgson, 492 F.2d 1175, 1177 (10th Cir. 1974) (absent confidentiality, the privilege does not apply; payment of a fee is not normally matter of confidential communication); In re Semel, 411 F.2d 195, 197 (3d Cir.) ("In the absence of unusual circumstances, the fact of a retainer, the identity of the client, the conditions of employment and the anount of the fee do not come within the privilege of the attorney-client relationslip."), cert. denied, 396 U.S. 905 (1969); Colton v. United States, 306 F.2d 633, 637 (2d Cir. 1962) (circumstances of retainer not normally covered by the privilege "even though the fact of having retained counsel may be used as evidence agaimst the client"), cert. denied, 371 U.S. 951 (1963).

In one recent Ninth Circuit case, the court of appeals appeared to abandon the incrimination approach it had led the way in developing. See In re Osterhoudt, 722 F.2d 591, 593 (9th Cir. 1983) ("Information regarding the fee arrangement ordinarily is not part of the subject matter of the professional consultation and therefore is not privileged communication even though it may evidence wrongdoing by the client.").

84. See Fisher v. Umited States, 425 U.S. 391, 398 (1976) ("[T] 'was never intended to permit [a person] to plead the fact that some third person might be incriminated by his testimony, even though he were the agent of such person .... [T] limited to a person who shall be compelled in any criminal case to be a witness against himself: ") (emphasis added) (quoting Hale v. Henkel, 201 U.S. 43, 69-70 (1906)); In re Grand Jury Proceedings (Wilson), 760 F.2d 26, 27 (1st Cir. 1985) (rejecting argument that fifth and sixth amendnents support a claim of privilege by attorney whenever client could refuse to answer the same question on the basis of client's privilege against self-incrimination); United States v. Haddad, 527 F.2d 537, 539 (6th Cir. 1975) (fifth amendment privilege is personal and "does not permit an attorney to plead that his client may be incriminated by his testimony"), cert. denied, 425 U.S. 974 (1976). 
coinpelling the government's need. ${ }^{85}$ The incrimination approach opens the door too wide when applied to facts other than those presented in Baird. For example, the Baird principle has been applied to protect the identity of a third party benefactor. ${ }^{86}$ Yet the relationship between the attorney and the third party benefactor is not one established by the benefactor in order that he inay personally obtain legal advice. Rather, the "relationship" involves a transfer of funds resulting in the retention of the lawyer as legal representative of some person or persons other than the benefactor. Because the benefactor, unlike the delinquent taxpayers in Baird, neither seeks nor receives legal advice from the lawyer, no privilege should apply and the benefactor's identity'should not be protected. ${ }^{87}$

\section{Constitutional Provisions.}

Some courts and commentators have intimated that sixth amendment concerns may provide a basis for limiting attorney-directed subpoenas. ${ }^{88}$ Additionally, lower federal courts have on occasion suggested that the due process clause constitutes a basis for some aspects of a right to counsel in grand jury proceedings. ${ }^{89}$ Commentators have periodically argued that further constitutional safeguards should be afforded to protect the right to counsel at the grand jury stage..$^{90}$

Under conventional analysis, lowever, the sixth amendment right to counsel does not attach at the grand jury stage, even where the client-

85. See S. Beale \& W. Bryson, GRand JuRy LaW and PRActice § 6:23 (1986).

86. See, eg., In re Grand Jury Proceedings (Jones), 517 F.2d 666, 674 (5th Cir. 1975).

87. See In re Grand Jury Proceedings (Freeman), 708 F.2d 1571, 1575-76 (11th Cir. 1983) (benefactors could not claim privilege because they were not attorney's clients in matter for which fee was paid and about which attorney was interrogated); Priest v. Hennessy, 51 N.Y.2d 62, 69-71, 409 N.E.2d 983, 987, 431 N.Y.S.2d 511, 515 (1980) (no attorney-client relationship arises out of payment of another's attorney's fees; if independent relationship is alleged to exist, its existence must be demonstrated by independent facts beyond the attorney's statement). But see Note, Benefactor Defense Before the Grand Jury: The Legal Advice and Incrimination Theories of the Attorney-Client Privilege, 6 CARDozo L. REv. 537, 560-61 (1985) (arguing that attorney's assertion that attorneyclient relationship exists should suffice because an attorney's word is entitled to respect, and that attorney-client relationship should be deemed to attaeh when client reveals faets to attorney tending to establish criminal liability).

88. In re Grand Jury Subpoena Served Upon Doe, 759 F.2d 968, 972 (2d Cir. 1985), vacated, 781 F.2d 238 (2d Cir.) (en banc), cert. denied, 106 S.Ct. 1515 (1986); In re Special Grand Jury No. 81-1 (Harvey), 676 F.2d 1005, 1011-12 (4th Cir), vacated on other grounds, 697 F.2d 112, 113 (4th Cir. 1982) (en banc); Note, Attorney-Client Privilege and the Right to Counsel for the Party Under Investigation, 19 WAKE FOREST L. REV. 487, 507-09 (1985).

89. See In re Taylor, 567 F.2d 1183, $1186 \mathrm{n} .1$ (2d Cir. 1977) ("[T] arbitrarily forbid [a grand jury witness] from retaining a particular attorney ... would deprive him of his constitutional right to due process of the law ...."); cf. In re Klein, 776 F.2d 628, 633 (7th Cir. 1985) (noting that fifth amendment due process clause might prohibit effort by government to "impose on the defendant the expense of paying multiple lawyers").

90. See Newman, The Suspect and the Grand Jury: A Need for Constitutional Protection, $11 \mathrm{U}$. RICH. L. REV. 1, 9-15 (1976); Note, supra note 88, at 507-09. 
witness is a target of a grand jury investigation. In Kirby v. Illinois, ${ }^{91}$ a plurality of the Supreme Court held that the sixth amendment right to counsel "attaches only at or after the time that adversary judicial proceedings have been initiated."92 Grand jury proceedings traditionally have not been identified as "adversary judicial proceedings." In United States v. Mandujano, ${ }^{93}$ another plurality of the Court considered and rejected the claini that one has a right to have counsel present in the grand jury room. ${ }^{94}$ Relying on Kirby, the plurality concluded that as applied to a grand jury witness, the sixtl amendment right to counsel has not yet "come into play." As Although Mandujano addressed only the question of the riglit to have counsel present in the grand jury room, postMandujano lower court decisions have generally embraced the broader proposition that the sixth amendment right to counsel does not extend to any aspects of grand jury representation. 96

As an alternative to sixth amendment analysis, the due process clause miglit be thought broad enough to comprehend cliallenges arising from attorney-directed subpoenas. In Powell v. Alabama, ${ }^{97}$ the Supreme Court asserted that the concept of due process historically included "the right to the aid of counsel when desired and provided by the party asserting the right." 98 The Court held that a defendant's right to counsel in-

91. 406 U.S. 682 (1972) (plurality opinion).

92. Id. at 688 .

93. 425 U.S. 564 (1976) (plurality opinion).

94. Id. at 581 .

95. $I d$.

96. See, e.g., In re Grand Jury Subpoena Served Upon Doe, 781 F.2d 238, 244 (2d Cir.) (en banc), cert. denied 106 S.Ct. 1515 (1986); United States v. Vasquez, 675 F.2d 16, 17 (2d Cir. 1982); In re Special September 1978 Grand Jury (II), 640 F.2d 49, 64 (7th Cir. 1980); In re Heuwetter, 584 F. Supp. 119, 125 n.5 (S.D.N.Y. 1984); In re Grand Jury Proceedings (Doe), 575 F. Supp. 197, 204 (N.D. Ohio 1983), aff'd, 754 F.2d 154 (6th Cir. 1985); United States v. O'Kane, 439 F. Supp. 211, 213-14 (S.D. Fla. 1977); United States v. DeRosa, 438 F. Supp. 548, 551 (D. Mass. 1977); aff'd, 582 F.2d 1269 (1st Cir. 1979).

Some lower federal courts have nevertheless employed sixth amendment standards when assessing the adequacy of advice tendered a grand jury witness or the adequacy of representation in instances of multiple representation. See, e.g., In re Gopman, 537 F.2d 262, 268 (5th Cir. 1976) (suggesting in dictum that qualified sixth amendment right to effective assistance of counsel applies to grand jury proceedings). Lower federal courts have also on occasion suggested that the fifth amendment privilege against self-incrimination and even the first amendment guarantees may constitute independent grounds for various facets of the right to counsel at the grand jury stage. See, e.g., United States v. Soto, 574 F. Supp. 986, 989-90 (D. Conn. 1983) ("[A] Grand Jury witness who has not been granted immunity may possess a constitutional right to counsel proceeding from the Fifth Amendment's privilege agamst self-incrimination ... if imdeed the Grand Jury witness' 'privilege against compulsory self-imcrimination is ... involved." ") (quoting United States v. Mandujano, 425 U.S. 564, 602 (1976) (plurality opinion)).

97. 287 U.S. 45 (1932).

98. Id. at 68 . 
cludes "a fair opportunity to secure counsel of his own choice." 99 And in Chandler v. Fretag, 100 the Court held that due process contemplates "a reasonable opportunity to eniploy and consult with counsel."101

In light of the charge tliat a grand jury subpoena may be issued with the ulterior motive of disqualifymg a target's chosen counsel, these Supreme Court decisions suggest a basis for arguing that fundamental fairness may be undermined unless strictures are imposed on attorneydirected subpoenas. ${ }^{102}$ It must be borne in mind, however, that in the due process right to counsel cases tlie individuals involved were, unlike a grand jury witness, parties to litigation. This distimction is significant because the basis of tlie due process right to counsel is the riglit to a fair hearing. ${ }^{103}$ Mere witnesses, unlike parties, are not entitled to a hearing and its panoply of mcidental procedural rights. ${ }^{104}$ Thus, reliance on the Powell-Fretag line of cases to place strictures on the issuance of attorney subpoenas in the course of grand jury proceedings appears to be foreclosed. ${ }^{105}$

Despite the adverse precedent discussed above, it has been argued that the attorney-chent relationship must be accorded special protection at the grand jury stage if the sixth amendment right to counsel is to have

99. Id. at 53.

100. 348 U.S. 3 (1954).

101. Id. at 10.

102. Cf. In re Klein, 776 F.2d 628, 633 (7th Cir. 1985) (noting that fifth amendment due process clause might prohibit effort by government to "impose on the defendant the expense of paying multiple lawyers ... in order to have a single defense"); United States v. Flanagan, 679 F.2d 1072, 1075 (3d Cir. 1982) (implying that the due process clause of the fifth amendment prevents the arbitrary dismissal of chosen counsel), rev'd on other grounds, 465 U.S. 259 (1984). But see In re Grand Jury Subpoena Served Upon Doe, 781 F.2d 238, 246 (2d Cir.) (en banc) (rejecting argument tlat grand jury target's "due process rights under the Fifth Amendment are more expansive than the protection which the Sixth Amendment affords and therefore would require a greater showing before the government can enforce the subpoena" issued upon attorney), cert. denied, 106 S.Ct. 1515 (1986).

103. See Powell v. Alabama, 287 U.S. 45, 69 (1932) ("If in any case, civil or criminal, a state or federal court were arbitrarily to refuse to hear a party by counsel, employed by and appearing for him, it reasonably may not be doubted that such a refusal would be a denial of a hearing, and, therefore, of due process in the constitutional sense.") (emphasis added).

104. See Blair v. United States, 250 U.S. 273, 282 (1919). The Court in Blair stated:

[The grand jury witness] is not entitled to urge objections of incoinpetency or irrelevancy, such as a party might raise, for this is no concern of his. ... [Nor is he] entitled to challenge the authority of the court or of the grand jury, provided they have a de facto existence and organization.... [Nor is he] entitled to set limits to the investigation that Id. at 282 .

the grand jury may conduct.

105. See S. BEALE \& W. BRYSON, supra note $85, \S 6: 17$, at 95 . Beale and Bryson conclude, however, that a due process theory would be an attractive basis for the right to counsel in the grand jury context because of its flexibility: it could be extended on a case-by-case basis; it would not necessarily imply a corollary right to appointed counsel for grand jury witnesses; and courts would be allowed to respond to the unique features and requirements of the grand jury without being obliged to extend the same protection to witnesses subpoenaed in other contexts. Id. 
any meaning subsequent to indictment. ${ }^{106}$ The propriety of extending relief on such grounds is rendered questionable by Supreme Court decisions demonstrating an unwillingness to extend constitutional protection to the period preceding indictment-even where significant rights of the prospective defendant stand to be affected. ${ }^{107}$ Because the recognition of constitutional restrictions on a prosecutor's ability to subpoena an attorney to appear before a grand jury would arguably entail fewer costs than the forms of rehief requested in those decisions, however, the Supreme Court might be willing to countenance the imposition of such restrictions. Presumably, such protection would involve a judicial determination that an attorney-chient relationship exists and that the information sought is essential to a successful investigation. Militating against the sanctioning of such rehef are judicial reluctance to disrupt grand jury proceedings with "mini trials" 108 and the difficulty of measuring the importance of the information to the grand jury investigation before the investigation is over and all the evidence is gathered. Where later constitutional trial rights stand to be substantially affected, however, courts might nevertheless be willing to countenance this limited and relatively unburdensoine imposition.

Even if such relief remains unavailable, the fact that the attorney is subpoenaed and testifies before the grand jury should not in itself be determinative of a later notion to disqualify the attorney from representing the chent at trial. Like motions to disqualify on other grounds in the grand jury context, such a motion should be judged according to the qualified sixth ainendment right to counsel of one's choice. This issue will be discussed with greater detail in the section that follows.

\section{The Department of Justice Guidelines: Compliance, Application, and Proposed Revisions}

The preceding discussion detailed the technical and theoretical objections that may be raised against the various proposals for insulating the target's attorney from the grand jury subpoena. Yet this analysis should not obscure the primary objection to these alternative approaches: in inany instances, the function of the grand jury to discover criminal

106. In re Grand Jury Subpoena Served Upon Doe, 759 F.2d 968, $972-73$ (2d Cir. 1985), vacated, 781 F.2d 238 (2d Cir.) (en banc), cert. denied, 106 S.Ct. 1515 (1986).

107. See, e.g., Kirby v. Illinois, 406 U.S. 682, 690 (1972); (refusing to impose per se exclusionary rule upon testimony concerning identification of defendant who had uot been advised of right to counsel where the identification was made prior to the initiation of prosecution); Hoffa v. United States, 385 U.S. 293, 309-10 (1966) (rejecting argument that sixth amendment was violated because government continued to question defendant without observance of his right to counsel at time when government allegedly had sufficient ground to bring charges).

108. United States v. Calandra, 414 U.S. 338, 349-50 (1974). 
activity promptly and to bring properly founded charges would be frustrated were the grand jury's access to probative nonprivileged information possessed by the attorney restricted.

In light of the public's interest in maintaining a viable defense bar, however, the executive branch has a critical responsibihty to avoid using its powers in ways that unnecessarily impair the attorney-client relationship. Placing questions of effective compliance aside for the moinent, the new guidelines issued by the Department of Justice provide an appropriate framework for the exercise of that responsibility.

The guidelines set out an explicit procedure to be followed in every case where a prosecutor seeks to subpoena an attorney. They first require that the prosecutor receive the approval of an Assistant Attorney General. ${ }^{109}$ This approval is to be based upon a determination (1) that the information is reasonably needed for the successful completion of the investigation; ${ }^{110}$ (2) that the government has unsuccessfully made reasonable attempts to obtain the information from alternative sources ${ }^{111}$ and voluntarily from the attorney through the medium of informal negotiations; ${ }^{12}$ (3) that the need for the information outweighs the risk that the attorney will be disqualified; ${ }^{113}$ (4) that the information is not protected by a valid claim of privilege; ${ }^{114}$ and (5) that the subpoena is directed at material information regarding a limited subject matter. ${ }^{115}$

Viewed in the abstract, these guidelines are superior to the alternative approaches discussed above. Unlike the supervisory power solution, the guidelines do not contemplate the imposition of extra-executive constraints and therefore do not pose troublesome separation of powers implications. ${ }^{116}$ And in contrast to an expanded privilege regime, the guidelines have an inherent, and substantial, degree of flexibility. Under the guidelines, "the approach must be to strike the proper balance between the public's imterest in the fair administration of justice and effective law enforcement and individual's right to the effective assistance of counsel."117 A good faith application of this balancing primciple would

109. USAM, supra note $5, \S 9-2.161(\mathrm{a})(\mathrm{D})$.

110. Id. $\S 9-2.161(\mathrm{a})(\mathrm{F})(1)$.

111. Id. § 9-2.161(a)(B); cf. United States v. Cortellesso, 663 F.2d 361, 363 (1st Cir. 1981) (rejecting arguinent that government must show that evidence is unobtainable from other sources when compliance with such requirenient would force government to settle for less than its best evidence).

112. USAM, supra note $5, \S 9-2.161(\mathrm{a})(\mathrm{C})$.

113. Id. \& 9-2.161(a)(F)(4).

114. $1 d$. $\S 9-2.161(\mathrm{a})(\mathrm{F})(6)$.

115. Id. $\S 9-2.161(\mathrm{a})(\mathrm{F})(5)$.

116. The guidelines contain a forceful disclaimer to the effect that they are not intended to create any judicially enforceable rights. Id. $\S 9-2.161$ (a).

117. Id. $\S 9-2.161(\mathrm{a})(\mathrm{A})$. 
bar use of the grand jury subpoena for the purpose of harassment, including the kind of covert abuse not readily discernible by courts.

\section{A. The Prospects for Compliance.}

The guidelines are vulnerable to the criticism that good faith apphcation may not be forthcoming. Critics are quick to label any self-monitoring approach as ineffectual and cosmetic. In this case, however, both internal incentives and external constraints should combine to produce effective conipliance. First, the Department of Justice has a clear institutional interest in policing attorney-directed subpoenas according to the flexible plan contained in the guidelines. By developing a record of demonstrated good faith conıpliance with the guidelines, the Department of Justice would successfully preempt the judicial imposition of measures more restrictive of its prerogatives. ${ }^{118}$ On the other hand, failure to follow the self-imposed guidelines would only add fuel to the moinentum currently building for a judicially fashioned solution.

Second, it appears that the Department's guidelines for issuing subpoenas to newsreporters (after which the present guidelines are closely modelled) ${ }^{119}$ have been effective. Although comprehensive statistical support is unavailable, there is evidence that the institution of those guidelines had the effect of reducing the number of federal subpoenas issued upon members of the news media. ${ }^{120}$

Third, although the guidelines expressly purport to create no judicially enforceable rights, ${ }^{121}$ some courts have demonstrated a willinguess

118. The promulgation of agency regulations is often spurred by threatening legislative or judicial action. See The Supreme Court, 1978 Term, 93 HARv. L. REv. 1, 118 (1979).

119. Reporter Subpoena Guidelines, 28 C.F.R. $\$ 50.10$ (1985).

120. See Ervin, In Pursuit of a Press Privilege, 11 HARv. J. Legis. 233, 252-53 (1974).

121. USAM, supra note $5, \S 9-2.161$ (a) coucludes: "These guidelines . . . are set forth solely for the purpose of internal Department of Justice guidance. They are not intended to, do not, and may not be relied upon to create any rights, substantive or procedural, enforceable at law by any party in any matter, civil or criminal . ..." The United States Court of Appeals for the Seventh Circuit has stated that defendants may not rely on the courts to apply and enforce these guidelines. In re Klein, 776 F.2d 628, 635 (7th Cir. 1985); see also In re Grand Jury Subpoena Served Upon Doe, 781 F.2d 236, $245 \mathrm{n} .1$ (2d Cir.) (en banc) (rejecting argument that attorney subpoena guidelines are to be judicially enforced: "That the government does not issue such subpoenas at whim is hardly a concession that the government also believes that a heightened showing, assessed by the courts, is required before an attorney may be called to appear before the grand jury."), cert. denied, $106 \mathrm{S.Ct}$. 1515 (1986). Other provisions in the Attorney's Manual contain similar language, and federal courts have generally respected these disclaimers. See, e.g., United States v. Schulman, 466 F. Supp. 293, 300 (S.D.N.Y. 1979) ("[T]here are more than enough exceptions, caveats, provisos and limiting adjectives in the [United States Attorney's Manual] guidelines as to make them practically worthless and illusory as a basis for seeking judicial interposition between the United States Attorney and his daily tasks."). See generally S. BEALE \& W. BRYSON, supra note $85, \S 10: 21$. Courts have refused to dismiss indictments on the basis of the government's noncompliance with Attorney's Manual guidelines concerning grand jury testimony of targets, see In re Tierney, 465 F.2d 806, 813 (5th Cir. 1972), 
to consider the extent of comphance with other internal standards when confronted with challenges alleging prosecutorial misconduct before the grand jury. ${ }^{122}$ The possibility that these guidelines would also be used by courts as an objective measure of the extent of prosecutorial misconduct should influence the seriousness with which the subpoena authorization procedures are observed.

\section{B. Disqualification.}

The guidelines' treatment of one of the most common objections to attorney-directed subpoenas-that the government may issue grand jury subpoenas with the illicit purpose of ultimately disqualifying counselmerits particular attention. ${ }^{123}$ The Code of Professional Responsibility directs that an attorney shall withdraw from continued representation when it becomes "apparent that his testimony is or may be prejudicial to his chent." 124 Critics of attorney subpoenas have pointed to this ethical directive and have charged that the prosecutor can unilaterally use the grand jury subpoena as a vehicle to disqualify a potential defendant's chosen counsel.

cert. denied, 410 U.S. 914 (1973), and forthwith subpoenas, see United States v. Wilson, 614 F.2d 1224, 1227 (9th Cir. 1980).

The Supreme Court addressed the judicial enforceability of administrative standards in United States v. Caceres, 440 U.S. 741 (1979). Prior to Caceres, some courts of appeals used a due process theory to invalidate government action taken in contravention of agency regulations. See, e.g., United States v. Sourapas, 515 F.2d 295 (9th Cir. 1975) (evidence obtained in IRS investigation suppressed where agents had failed to give Miranda-like warnings as required by IRS regulations). In Caceres, however, the Court held that tape recordings made by IRS agents in violation of an IRS regulation were admissible in a criminal prosecution. The Court concluded that compliance with the regulation was not constitutionally or statutorily mandated. Id. at 749-51. The Court further noted that the IRS agents had acted in good faith, id. at 752, and that the defendant had not detrimentally relied upon the IRS regulation. Id. at 752-53. The scope of Caceres might be restricted by giving weight to these latter two factors. See The Supreme Court, 1978 Term, 93 HARv. L. Rev, 1, 118 (1979). An argument for the judicial enforcement of the attorney subpoena guidelines is therefore not entirely foreclosed by the Supreme Court's decision in Caceres.

122. See United States v. Sears, Roebuck, and Co., 518 F. Supp. 179, 185 (C.D. Cal. 1981) (violation of Department of Justice's policy regarding forthwith subpoenas "relevant . . . to set the tone of this entire investigation and defines at the outset the overreaching of the government in its presentation to the Grand Jury"), rev'd on other grounds, 719 F.2d 1386 (9th Cir. 1983), cert. denied, 465 U.S. 1079 (1984); cf. United States v. Blanton, 534 F. Supp. 295, 297 (S.D. Fla. 1982) (subpoena issued upon reporter quashed; Department of Justice guidelines governing reporter subpoenas had not been followed).

Some courts have suggested that fiagrant and entrenched violations of agency regulations might justify judicial intervention on a supervisory power basis. See United States v. Wilson, 614 F.2d 1224, 1228 (9th Cir. 1980); United States v. Myers, 510 F. Supp. 323, 328 (E.D.N.Y. 1980).

123. See supra note 28 and accompanying text.

124. Model Code of Professional Responsibility DR 5-102(B) (1979). But see Rice v. Baron, 456 F. Supp. 1361, 1370 (S.D.N.Y. 1978) (noting that DR 5-102(B) was "not designed to permit a lawyer to call opposing counsel as witness and thereby disqualify him as counsel") (citations omitted). 
The guidelines respond to this concern by providing that a "reasonable need" for the information sought "must outweigh the risk that the attorney will be disqualified from representation of the client as a result of liaving to testify against the client."125 "Reasonable need" as used in this context presumably is a shorthand for the other requirements listed in the text-that the information be material, that reasonable attempts have been made to obtain the information from alternative sources, and that the information be reasonably necessary for the successful completion of the investigation.

Assuming an absence of improper prosecutorial motive, if all of the criteria set out in the guidelines are found to exist, there is no reason why the potential for disqualifying counsel should by itself preclude compelled disclosure. Attorneys, like other citizens, are duty-bound to aid a grand jury in its investigation. ${ }^{26}$ Society's interest in preserving an attorney-client relationship, insofar as that interest is founded upon the behef that such relationships are instrumental to the fair administration of justice, must yield when sheltering tlrat relationship would preclude achieving a just result. ${ }^{127}$

Tlius, in terins of the public interest, the prospect that some attorneys will be disqualified is not intolerable. An intolerable situation would arise, however, were it in fact the case, as critics charge, that prosecutors could automatically disqualify defense attorneys by issuing a grand jury subpoena. Such abuse clearly would be possible if an attorney's compelled appearance before a grand jury investigating his client automatically precluded his representing that chent at trial. However, disqualification is not the inevitable result.

The charge that an appearance before the grand jury automatically spells disqualification is without foundation. The attorney who has appeared before a grand jury sliould, in many cases, succeed in resisting a later trial subpoena. ${ }^{128}$ The attorney will only be disqualified from representing the client at trial if a court determines that his testimony is

125. USAM, supra note 5, \$ 9-2.161(a)(F)(4).

126. See In re Kinoy, 326 F. Supp. 400, 402 (S.D.N.Y. 1970) (lawyers "are obliged . . . not less than others, to give their non-privileged knowledge to the grand jury").

127. See United States v. Cortellesso, 663 F.2d 361, 363 (1st Cir. 1981) ("It is inconceivable that defendant's right to a particular counsel should be permitted to impose [substantial] artificial disadvantages upon the government."); United States v. Weninger, 624 F.2d 163, 166 (10th Cir. 1980) ("A defendant's right to obtain counsel of his choice must be balanced against the need for the efficient and effective administration of criminal justice."), cert. denied, 449 U.S. 1012 (1980); United States v. Bentvena, 319 F.2d 916, 936 (2d Cir. 1963) ("An accused's right to select his own counsel ... cannot be insisted upon or manipulated so as to obstruct the orderly procedure in the courts or to interfere with the fair administration of justice."), cert. denied, 375 U.S. 940 (1963).

128. See In re Grand Jury Subpoena Served Upon Doe, 781 F.2d 238, 245 (2d Cir.) (en banc), cert. denied, 106 S.Ct. 1515 (1986). The Doe court stated: 
needed at that trial. 129 Because the outcome of the determination directly impacts the chient's sixth amendment rights in a context-his trial-where such rights have clearly attached, such a determination necessarily mvolves a weighing of sixth amendment interests. ${ }^{130}$ Consequently, an unethical prosecutor's attempt to effect an attorney's disqualification via a grand jury subpoena will fail unless the court determines that a showing of need for the attorney's testimony at trial has been made which is sufficiently compelling to override the defendant's qualified sixth amendment right. Once such a showing of need is made, speculation as to the prosecutor's original motive in issuing the grand

Before disqualification can even be contemplated, the attorney's testimony must incrimi-
nate his client; the grand jury must indict; the government must go forward with the prose-
cution of the indictment; and ultimately, the attorney must be advised that he will be called
as a trial witness against his client. As a court, we decline to speculate that all those events
will occur.... . [The] attorney's grand jury testimony may be exculpatory or neutral, or
... the government may decide not to use such information at trial, or ... the information
may be presented at trial in such a way that the attorney can avoid testifying, or ... the
judge may mle in limine that the information is not admissible, perhaps because its proba-
tive force does not justify a resulting disqualification of counsel.

Id. (footnotes omitted). See also In re Klein, 776 F.2d 628, 633 (7th Cir. 1985) (finding unpersuasive the "likelihood of disqualification" objection to grand jury attorney subpoenas, and asserting that subsequent trial subpoena "is not the most likely consequence of the attorney's appearance before the grand jury").

129. See United States v. Cortellesso, 663 F.2d 361, 363 (1st Cir. 1981) (attorney's adverse testimony appeared in grand jury record; court nevertheless analyzes need for attorney's testimony at trial and concludes that client's sixth amendment rights did not bar requiring attorney to testify at trial where absence of testimony "would ... weaken the government's case directly by a serious diminution of the total evidence"); In re Rappaport, 558 F.2d 87, 91 (2d Cir. 1977) (unethical for lawyer to participate in a trial both as counsel and witness) (emphasis added).

The Model Code of Professional Responsibility provides that "[i]f, after undertaking employment in contemplated or pending hitigation, a lawyer learns or it is obvious that he or a lawyer in his firm may be called as a witness other than on behalf of his client, he may continue the representation until it is apparent that his testimony is or may be prejudicial to his client." MODEL CODE OF Professional RESPONSIBILITY DR 5-102(B) (1979). Obviously, if the testimony is not needed at trial, and the attorney is accordingly not required to testify, no prejudice accrnes and no ethical obligation to withdraw arises. In determining whether the attorney should be required to testify at trial, a court should bear in mind the admonition that DR 5-102(B) was "not designed to permit a lawyer to call opposing counsel as a witness and thereby disqualify him as counsel." Galarowicz v. Ward, 119 Utah 611, 620, 230 P.2d 576, 580 (1951). The Code apparently would not require disqualification in any event where the testimony sought relates solely to "the nature and value of legal services rendered . . . by the lawyer or his firm to the client." MODEL CODE OF Professional RESPONSIBILITY DR 5-101(B)(3) (1979).

130. See supra notes $91-96$ and accoinpanying text. A majority of the decisions addressing the issue of attorney disqualification on the grounds of conflict of interest in the grand jury context assume that the witness had a sixth amendment right to counsel of his choice. See In re Grand Jury Empanelled Jan. 21, 1975 (Curran), 536 F.2d 1009, 1011 (3d Cir. 1976); In re Gopman, 537 F.2d 262, 268 (5th Cir. 1976); In re Grand Jury Investigation, 436 F. Supp 818, 820 (W.D. Pa. 1977), aff'd, 576 F.2d 1071 (3d Cir.), cert. denied, 439 U.S. 953 (1978); In re Grand Jury Proceedings, 428 F. Supp 273, 277-78 (E.D. Mich. 1976); Pirillo v. Takiff, 462 Pa. 511, 521, 341 A.2d 896, 900 (1975), appeal dismissed, cert. denied, 423 U.S. 1083 (1976); see also In re Taylor, 567 F.2d 1183, 1186 n.1 (2d Cir. 1977) (suggesting that due process clause is implicated in disqualification motions in the grand jury context). 
jury subpoena becomes irrelevant, because the court has separately and independently determined that the attorney's testimony is needed at trial.

If the court determines that a sufficient showing of need for the attorney's testimony at trial has not been made, the attorney should not be compelled to testify at the trial and no disqualification should ensue. The defendant's qualified sixth amendment right to counsel of choice therefore would not be impaired as a consequence of a possible illicit prosecutorial motive for issuing the subpoena at the grand jury stage.

Thus, contrary to the charges levelled by several commentators, it remains the judiciary's, not the executive's, function and obligation to determine whether an attorney should be disqualified. ${ }^{131}$ It is reasonable to believe that an attorney may be compelled to give testimony potentially adverse to his client before the grand jury and yet still be ehgible to represent the chent at trial. Each branch-the executive and the judicial-must be allowed the full exercise of its prerogative within its constitutionally recognized sphere.

Even where the standard necessary to disqualify an attorney at trial is met, disqualification might still be avoided if the testimony in question relates to fee amounts. ${ }^{132}$ The guidelines should be revised to include a provision requiring that in cases involving testimony concerning fee amounts, the government request and accept a "sanitized" stipulation. Such a stipulation would merely state that the defendant possessed a spe-

131. Lower federal courts have suggested various formulas indicating the appropriate showing to be made in the context of a disqualification motion. See Grady v. United States, 715 F.2d 402, 404 (8th Cir. 1983) (attorney's withdrawal did not infringe defendant's right to counsel where attorney's testiniony was "important to the prosecution because it tended to establish . . . an element of [the defendant's] offense"); United States v. Cortellesso, 663 F.2d 361, 363 (1st Cir. 1981) (testimony of defendant's attorney could be required at trial where absence of such testimony "[n]ot ouly would ... weaken the government's case directly by a serious diminution of the total evidence, . . . [but] would create a singular question in the jurors' minds-how was it that [the attorney], the most significant witness, had not testified?'). Compare United States v. Crockett, 506 F.2d 759 (5th Cir.) ("[A] party's attorney should not be called as a witness unless his testimony is both necessary and unobtainable from other sources."), cert. denied, 423 U.S. 824 (1975) with United States v. Cortellesso, 663 F.2d 361, 363 (1st Cir. 1981) (government "not required to accede to this truncation of its evidence ... if it means that the government must settle for less than its best evidence") and United States v. Gomez, 584 F. Supp. 1185, 1188 (D.R.I. 1984) (refusing to "shackle" prosecution with requirement that evidence must be unobtainable froin other sources).

132. See In re Grand Jury Subpoena Served Upon Doe, 781 F.2d 238, 245 (2d Cir.) (en banc) (noting possibility that disqualification could be averted through use of a stipulation), cert. denied, 106 S.Ct. 1515 (1986); United States v. Castellano, 610 F. Supp. 1137, 1151 (S.D.N.Y. 1985) (stipulation to facts for proof of which government requires attorney's testimony may enable attorney to continue as counsel, "since 'uncontested' testimony does not require withdrawal"); In re Grand Jury Subpoena Duces Tecum Dated Jan. 2, 1985, 605 F. Supp. 839, 850-51 (S.D.N.Y.) (attorney could avoid appearing as grand jury or trial witness were defendant to supply fee information in sworn statements that could be admitted at trial either through stipulation or by testimony of nonconspirator witness), rev'd on other grounds, 767 F.2d 26 (2d. Cir. 1985). 
cific sum of money on a specific date. ${ }^{133}$ The fact that this sum was used to pay an attorney for legal services rendered need not be included in the stipulation; this detail is irrelevant where fee information is sought, for example, to establish the existence of substantial unexplained wealth on the part of the chent. ${ }^{134}$ Thus, the attorney would not have to testify at trial and disqualification would be averted. Even where information other than fee amounts is sought, a sanitized stipulation might effectively avert disqualification. ${ }^{135}$

\section{Proposed Revisions.}

The guidelines contain a number of deficiencies that should be corrected through revision. For example, the provision encouraging the

133. See In re Ousterhoudt, 722 F.2d 591, 594 (9th Cir. 1983) (holding that attorney-client relationship was not threatened where government required counsel to produce date, amount, and form of payment).

134. Cf. United States v. Jeffers, 532 F.2d 1101, 1115 (7th Cir. 1976) (fee information disclosed was simply an element of defendant's expenditures for a year; nothing more was elicited "than would have been ehicited by introducing evidence that the defendant had bought a Rolls-Royce for cash (i.e., a substantial expenditure)"), aff'd in part and vacated in part on other grounds, 432 U.S. 137 (1977).

135. United States v. Cortellesso, 663 F.2d 361, 364 (1st Cir. 1981) (the "whole counsel-witness issue would disappear" were defendant to have stipulated that agreement about which attorney's testimony was sought had been made).

In In re Grand Jury Subpoena Served Upon Doe, 759 F.2d 968 (2d Cir. 1985), vacated, 781 F.2d 238 (2d Cir.), cert. denied, 106 S.Ct. 1515 (1986), the court of appeals intimated that a stipulation as to fee arrangements would be ineffective to avert disqualification, citing the Third Circuit case, Government of Virgin Islands v. Zepp, 748 F.2d 125 (3d Cir. 1984). Doe, 759 F.2d at 973 n.6. It is questionable, however, whether Zepp stands for the proposition that a stipulation relating to any aspect of an attorney-chent relationship is necessarily invalid. In Zepp, a suspect and her attorney conferred alone inside the suspect's house while police officers waited outside. The officers heard a toilet flush several times. A subsequent search of the septic tank produced a number of glassine bags containing cocaine residue. After the suspect had been charged with possession, the parties agreed to a stipulation wherein the defendant's attorney stated that he did not flush any toilets while in the house. Zepp. 748 F.2d at 128-29.

The court of appeals found from these facts that there was an actual confict of interest that required disqualification of the attorney. Zepp, 748 F.2d at 136. The court emphasized that the attorney may have made the stipulation in order to avoid the possibility that he hinself would be incriminated. Id. at 136-39. As a further ground for its decision, the court asserted that the attorney, by making the stipulation, had in fact become a witness for the prosecution. Id. at 137. The court emphasized that the attorney's stipulation would tend to elininate doubt the jurors may have had as to whether it was in fact the defendant who had fushed the toilet while she and the attorney were alone in the house. Id. at 137.

The determinative factors in the Zepp decision simply would not be present in typieal cases where fee information is sought in the course of a grand jury investigation. The attorney would not normally be in a situation where he himself stood to be incriminated; the stipulation would therefore not have the effect of inculpating the client at the very same tine that it exculpates the attorney. If the defendant is permitted to proffer a "sanitized" stipulation, the jury will not be made aware that the amount stipulated to was paid in attorneys' fees, and therefore there will be no danger that the jury might get the impression from the stipulation that the defendant's own lawyer is presenting evidence against him. 
prosecutor to pursue negotiations ${ }^{136}$ with the attorney from whom information is sought may pose some potential for abuse. A similar provision is included in the Justice Department's guidelines governing the issuance of subpoenas to members of the news media. ${ }^{137}$ In that context such a provision is not objectionable because the privilege involved belongs to the reporter, not his source. An attorney, in contrast, is forbidden by the Code of Professional Responsibility to reveal a confidence or secret ${ }^{138}$ of his client, except when required by law or court order. ${ }^{139}$ The Code defines "secret" broadly to imclude information which "would be likely to be detrimental to the chent." 140 This definition might encompass the kind of unprivileged fee information that would be sought through the contemplated negotiations. Thus, bothersome ethical questions may arise froin the very fact that negotiations take place at all. ${ }^{141}$

A structure for negotiations, however, would in many cases be desirable and in the best interest of the chient under investigation by the grand jury. The perceptive defense attorney representing the target witness may be able to gauge the direction of the grand jury's investigation by the tenor of such negotiations. Moreover, based on discussions with the attoruey and an evaluation of the nature of the evidence within the attorney's possession, the prosecutor may decide that the case against the client was weaker than previously behieved and may consequently drop or refocus the investigation. On the other hand, however, personal considerations-such as a desire to avoid becoming personally imphicated in the criminal activity - nnay induce the attorney to make inappropriate disclosures in order to avoid a professionally damaging appearance before the grand jury. Thus, while the informal negotiations contemplated by the guidelines should normally benefit the client under investigation, their availability may tempt some attorneys to make disclosures that are not in their clients' best interests.

The guidelines could preserve the beneficial aspects of negotiations while avoiding this ethical problem if revised to require that no negotiations be conducted in the client's absence. Although the client's presence might dampen the candor or frankness of the negotiations, it would also diminish the likelihood that the lawyer might inadvertently disclose client "secrets" or deliberately divulge client confidences in order to avoid a grand jury appearance.

136. USAM, supra note 5 , $\$ 9-2.161(a)(C)$.

137. Reporter Subpoena Guidelines, 28 C.F.R. $\$ 50.10(\mathrm{c})$ (1985).

138. MODEL CODE OF PROFESSIONAL RESPONSIBILITY DR 4-101(B)(1) (1979).

139. Id. DR 4-101(C)(2).

140. Id. DR 4-101(A).

141. ABa Grand Jury Committee, Proposed Standards for Calling of Lawyers as GRAND JURY WITNESSES 3 n.l (1985). 
Unnecessary erosion of attorney-client trust could also be avoided by requiring that prosecutors allow the subpoenaed attorney the option of either appearing before the grand jury in person or submitting written answers to interrogatories. ${ }^{142}$ This procedure would allay the fear expressed by some commentators that an attorney's appearance behind the closed doors of the grand jury room in and of itself puts a chill on client trust. ${ }^{143}$ Although such a procedure would deny the grand jurors the opportumity to assess the attorney-witness's deineanor, the use of transcript testimony before the grand jury has been sanctioned by courts in a variety of circumstances when deemed expedient. ${ }^{144}$ Providing this option would admittedly smack of special treatment for lawyers; it would not, however, have the effect of restricting government access to the information sought. Impairment of attorney-chent trust could be further minimized if the guidelines required that the chent be provided with a transcript of the attorney's grand jury testimony. Such a practice would not contravene the policy of grand jury secrecy, because any witness is free to reveal his grand jury testimony to a third party, ${ }^{145}$ and presumably the attorney would communicate the content of his testimony to the client.

\section{CONCLUSION}

The Department of Justice's guidelines goverming the issuance of subpoenas upon attorneys merit serious consideration for a number of reasons. First, on a practical level, the alternative approaches discussed in this note have not enjoyed widespread acceptance. Instead, a number of courts have found these proposals insupportable under existing case law. Thus far, only the supervisory power approach has won any degree of judicial acceptance, and even that acceptance has been sharply limited.

Second, when compared to the supervisory approach, the guidehines emerge as the more appropriate response in hight of separation of powers considerations. The supervisory power approach, because it lacks a statutory or constitutional predicate, impermissibly interferes with the exec-

142. Cf. In re Osterhoudt, 722 F.2d 591, 594-95 (9th Cir. 1983) (concluding that attorney-client relationship was not impaired and noting that attorney was offered option of providing information without having to appear before the grand jury); In re Grand Jury Proceedings, 568 F.2d 555, 556 (8th Cir. 1977) (noting that trial court had conditionally quashed attorney-directed subpoena provided that attorney answer written interrogatories or appear in person), cert. denied, 435 U.S. 999 (1978).

143. See In re Special Grand Jury No. 81-1 (Harvey), 676 F.2d 1005, 1009 (4th Cir.), vacated on other grounds, 697 F.2d 112 (4th Cir. 1982) (en banc).

144. See S. BEALE \& W. BRYson, supra note $85, \S 10: 07$.

145. Rule 6 of the Federal Rules of Criminal Procedure imposes no obligation of secrecy on grand jury witnesses. See In re Russo, 53 F.R.D. 564 (C.D. Cal. 1971). 
utive functions of federal prosecutors. This note has sought to expose the weakness of the charge often levelled by apologists for the supervisory power approach that a federal prosecutor armed with a grand jury subpoena "controls the right to counsel." Two factors have been identified that suggest that such a charge is ill-founded. First, courts will entertain motions to quash attorney subpoenas on the ground of oppressiveness. Second, motions to disqualify an attorney who has testified before the grand jury will be judicially determined and will be tested according to standards developed to protect the qualified sixth amendment right to counsel of one's choice.

To the extent that the right to counsel is judicially protected in these respects, grand jury access to the testimony it seeks should not otherwise be subject to judicial restriction. Each branch should be allowed the full exercise of its discretion within its proper sphere. As applied to grand jury subpoenas, the guidelines provide a prudent formula for self-restraint within a sphere recognized as the proper domain of executive discretion. External restraint would impermissibly impair the grand jury's abihty to carry out its mandate to mvestigate criminal activity and to bring charges where appropriate. 